\title{
Intercultural communication skills development as a basic requirement in the multicultural world
}

Streszczenie: W tekście prezentuję taki sposób rozumowania, zgodnie z którym rozwój zdolności komunikacyjnych w zakresie komunikacji międzykulturowej jest złożonym procesem, który przynosi najlepsze efekty, jeśli jest motywowany wewnętrznie - indywidualnymi dążeniami podmiotu. Takie motywacje pomagają, a w zasadzie tylko one umożliwiają zrozumienie Innego, w oparciu o przekraczanie własnych granic poznawczych. Wrażliwość na różnice kulturowe, świadomość tego, jakie one są i jak można je wyznaczać, podnoszą poziom empatii. Wzmacnianie kompetencji kulturowych w zakresie komunikacji międzykulturowych sprzyja rozumieniu innych, osób reprezentujących najróżniej definiowane grupy i kategorie społeczne. Sprzyja to redukowaniu zjawiska „niewidzialnych grup” - takich, które są postrzegane jako niekomfortowy pratner komunikacyjny, którego się unika.

Słowa klucze: komunikacja, kompetencje międzykulturowe, wielokulturowość, grupy niewidzialne, grupy marginalizowane

Your Christ - Jewish

Your car - Japanese

Your pizza - Italian

Your democracy - Greek

Your coffee - Brazilian

Your holidays - Turkish

Your numbers - Arabic

Your letters - Latin

And only your neighbour

- a stranger?

\section{Visibility and underprivileged groups}

Visibility is an interesting phenomenon defining the so called post-industrial countries. The contemporary human orientation towards visuality, has almost excluded other forms of communication, what is visible seems to be 
present, while invisible means excluded. This interesting metaphor of presenting visual material, visualizing and making visible is more and more often applied to minority groups of various kinds. Providing visibility allows improving the situation of the given minority group, which is not precisely seen by majority of the community or society. What is however interesting: visibility of social groups is not only a metaphor. This is also a social and communicational fact. Some evidence was delivered recently in random participating observation situation: in the waiting room of the medical clinic, two ladies appeared entering together: young and old one, obviously a family. Approached the registration counter and older one says what she needs. The registration clerk answers: directing her speech to young lady. In such situation many questions raise, but the main one is probably the one: why registration clerk seems not to notice old lady, although she is the one speaking?

This question "why registration clerk seems not to notice old lady, although she is the one speaking?" can be put in the situation of any other representative of "underprivileged" (?) group. Also in case of ethnic minorities, where probably it is even more likely, that the client representing ethnic minority will not be visible enough or will not be noticed. The minority groups which I call underprivileged groups here can be defined as groups lacking opportunities or advantages enjoyed by other members of one's community. The "status" of the underprivileged group can be subjective or objective, but in all cases it is relative. What can be perceived as a minority - underprivileged group in one sense, in another environment can be treated as the regular group enjoying all privileges and rights? In general underprivileged groups are minority group. There seems to be one exception - and this is the ageing group of elderly (broadly speaking), which soon will have to be perceived and treated as a majority group. This is the group rapidly growing in number, yet still treated and considered in many social areas as underprivileged-minority group (this is the status that seniors get for example in widely understood Western European societies, although many claim more and more loudly that this group becomes to be dominating in numbers).

Invisibility of certain social groups can be analyzed as social consequence of psychological issues. It certainly would qualify under one of the strategies of reducing cognitive dissonance - in situations where one lacks language skills or any other communicative skills, it is better to "ignore the presence" of the other in order to save own social face and in order to avoid direct confrontation. Cognitive dissonance is used to describe the feeling of discomfort when simultaneously holding two or more conflicting cognition: ideas, beliefs, val- 
ues or emotional reactions. In a state of dissonance, people may sometimes feel "disequilibrium": frustration, hunger, dread, guilt, anger, embarrassment, anxiety, etc. (Festinger, 1957). Because the emotional consequences of cognitive dissonance are unpleasant, human beings are usually motivated to reduce dissonance by altering existing cognitions, adding new ones to create a consistent belief system, or alternatively by reducing the importance of any one of the dissonant elements (Festinger, 1957). It is widely observed that in order to avoid cognitive dissonance people avoid confrontations with situations which create emotional difficulty, by providing contradictory information.

One of such situations creating cognitive dissonance is the situation of ineffective communication, especially if one can judge right-away that the situation will be difficult to handle. This happens very often in stations of lacking communication skills, especially language skills. This fact outs in very inconvenient position representatives of all types of ethnic minority groups. Therefore it seems to be crucial nowadays to stress and enhance communicative skills and their improvement. This is even more important due to specific situation of postmodern societies where globalization causes difficult situation of melting all cultures and blending communicative styles. In such context the knowledge from the area of multicultural context and skills that can be used in this context are of a very high importance.

Self confidence in own skills of the subject, allows involvement into new situations, also communication situations. Therefore subject that is self confident feels no fear in addressing others, also those - who can potentially be more challenging partners in communication process. It is necessary to mention that the pre-judgements made by subject in given situation do not have to be rational. Moreover - most often they are not rational. This, very easily, may lead to the situation, when subject lacking self-confidence in communication skills, avoids contact with others. Especially those others, who seem to create more challenge in the communication process. For this reason, young lady serving clients, described at the beginning of the text, addresses someone who is more similar to her. Instead of facing potentially difficult communication with older person, she chooses what she perceives as easier situation: communicates to someone who is more similar to her.

\section{The basic notions: culture and multiculturalism}

Social minorities of various kinds, but especially ethnic minorities are often treated in majority of the society as the group which is invisible or should 
be treated as invisible. The issue of minorities and the way society treats them, becomes more and more important due to increasing multiculturalism. Therefore invisibility of ethnic and cultural minorities becomes an issue to be solved in each society, which makes it worth to think on how cultural differences influence our daily life. As stated before, the competencies allowing the cultural understanding and communication are crucial in improving the well being of cultural "invisible groups".

The notion of culture is the crucial one for dealing with the issue of cultural invisible groups. The way culture is defined influences further understandings of all processes related to ethnic and cultural minorities and regulating their functioning in the contemporary world. In this text I refer to culture understood in terms of I refer to this as the socio-regulatory concept of culture (Banaszak and Kmita, 1991), according to which culture is defined as a set of norms and directions that are respected and known in given social group. This is worth to emphasize that the culture here has no ethnic meaning only - it is not limited to national differences. Culture is understood as a broad concept which can characterize not only given ethnic group, but any group. In traditional thinking about culture, this notion was closely linked with ethnic differences, and moreover: it was always sure that if one speaks about "culture" means something that is linked to certain territory and certain group living on this territory. The socio-regulatory concept of culture changes this understanding significantly: in this very broad sense culture can characterize professional groups, ethnic groups, groups belonging to certain organization etc. I find this approach very useful especially in terms of speaking about traditionally understood cultural differences: those are no longer limited to certain territory. Together with overwhelming process of globalization contemporary society encounter situation in which mixing of ethnic groups is the constant process. This way we face new cultural phenomenon: one can no longer state that there is something like British or German culture. Those cultures (and all other types of cultures) are influenced by the presence of The Others: those who share different values and different norms, who follow different behaviours and who believe in different social rules. The wonderful illustration for this situation is the citation presented at the beginning of this text.

The text cited was displayed in 1991 on the billboards in Berlin/Germany. The German government decided that there is significant need for social campaign educating citizens about their cultural links with other nations. The direct stimuli causing this situation was the situation caused by relatively 
good at this time economy in Germany. Based on positive economical situation Germans opened options of legal work for Turkish citizens arriving to Germany. This originally short-term plan, exceeded expectations of both parties. Turkish citizens have arrived to Germany, settled down and began to seek for permanent stay permissions. This situation caused at least fear among German citizens who were not prepared for such a situation. In order to deal with it, German government decided to start social campaign helping citizens to understand how much there are linked with other cultures, even if they think that given elements belong only to the German culture. The text in citation illustrates inspiring phenomenon human flexibility and ability to adapt to the situation. At the same time it shows contrary tendency - we like living in the world that we know, and which is stable and does not change.

In this changing world the notion of culture needs redefinition - therefore, understanding proposed above and referring to socio-regulatory concept of culture seems to be very suitable. While one still can speak nowadays about certain cultural differences, thinking of this in the context of socioregulatory concept of culture broadens perspective. In this sense also the term "multiculturalism" changes its meaning: this is no longer co-habitation of at least two different ethnic groups beside each-other. Multiculturalism should be understood as widely defined coexistence of two, or more, groups having distinctive qualities. Worth to mention: this coexistence may take other, than only peaceful forms.

\section{Multiculturalism}

As phenomenon multiculturalism has been always present in human lives; however it used to the different forms in the past and nowadays. The past multiculturalism was a random and rare phenomenon being observed by only selected groups of people. The traditional societies very much tided to the land they were living on, were limited in mobility and moreover - mobility was treated as a risky business. Those travelling to other places in the world were usually treated as exceptions, human beings living outside of the dominant social rules. Those travelling around were usually representing: traders, soldiers and troublemakers of various kings (beggars, Gypsies, suspected comic groups etc). The "proper" citizen did not travel: did not have a reason to travel. All his relatives used to live close-by; the world outside own village or city was dangerous and full of various risks (predators animals and mentioned already thieves and burglars). Due to technical limitations mobil- 
ity would take a lot of time and contact with those who have left their own space, was practically impossible. Over centuries, this situation has changed to the point, where one faces absolutely opposite situation. Travelling is the must. If one claims, he doesn't enjoy travelling - is treated as some kind of exception from the normality. Dynamic technological development created the situation of shrinking of the world - using low-fare airlines; one can fly all over the world and reach all possible destinations. In the worst case: one can switch on television and foreign regions become closer than anything else. Multiculturalism nowadays becomes everyday life, intensified by smooth and cheap communication technologies (in both meanings: transportation and maintaining contact with others); globalization. In addition two interesting processes strengthen multiculturalism. Those are processes of deconstruction and construction. The process of deconstruction can be illustrated by falling of old systems apart which causes serious changes in organization of the world present in Cold War period (divisions of former socio-political structures former Soviet Union, Former Yugoslavia and Czechoslovakia). Opposite process of constructing bigger than national entities is also faced: countries create Unions (like European Union), which also forces membering countries to meet cultural differences demonstrated by each other. Fall of the communism in late 80's and in 90's allowed more and more intense exchange with Western world. All those processes can be analyzed in detail; however it is important to note that they do create a specific environment for analyzing multiculturalism as inevitable element of our lives.

In terms of theoretical approaches to multiculturalism as phenomenon there are a number of representatives thinking of multiculturalism in various ways, sometimes significantly differing from each other. Probably most known in this area are the views of Will Kymlicka $(1991,1996)$, Canadian thinker, liberal and politically involved academic, claiming that multiculturalism should be respected by states as the policy guarantying equality and equal chances to all members of the modern society.

This Canadian French-English-Indigenous environment was also inspiring for Charles Taylor (1991), who in his works widely analyzes multiculturalism and treats it as a must in terms of effective and friendly community development, serving well being of its members. Taylor in his works presents communitarian critique of liberal theory's understanding of the self, and claims that although nowadays each human being is responsible for his or her own self construction, one cannot do it based on "pure relationships". This is the term coined by Taylor in order to describe such type of human rela- 
tions which are maintained only as long as they provide positive emotional fulfilment. Human relations of this type disappear as soon as they loos the satisfactory power. Such a situation leads to the critical point in which one cannot count on any support unless provides some kind of "payment". This "payment" is usually made in form of positive emotions. Taylors underlines, that such kind of relationships, if dominant in society - create unbearable social environment, which is selfish, self-oriented and closed to others' needs. Being communitarian himself, Charles Taylor claims that the power and the quality of every day human life is located in friendly and open communities, and that importance of social institutions in the development of individual meaning and identity is really significant.

Some of the experts (Bennet, 1998; Kohls and Knight, 1994; Stroti, 1994) dealing with issues of complexity in contemporary societies, prefer to use the term interculturalism to the term multiculturalism. Interculturalism is understood here as a philosophy of exchanges between cultural groups within given society - the dynamic element is crucial here. The main objective of following this approach is to develop a common civic culture based on the values of freedom and liberty, and of human rights, as derived from the Western civilization and encouraging interaction between the communities living in the same country, area, space. As such, Interculturalism requires democracy and full respect for universal human rights

Last but not least - the term of "Transculturalism" was coined by Cuban anthropologist Fernando Ortiz in 1947 (Duno-Gottberg, 2003) to describe the phenomenon of merging and converging cultures. According to Ortiz Transition means not only acquiring another culture, which is what the word acculturation implies but it also involves the loss of a previous culture (deculturation) and carries the idea of the consequent creation of new cultural phenomenon, which could be called neoculturation. Ortiz also referred to the devastating impact of Spanish colonialism on Cuba's indigenous peoples as a "failed transculturation"

\section{Differences in intercultural communication}

Brief presentation made above shows already, not only how difficult it is to define multilateral cultural contacts, but also how fragile issue we deal with, not only on theoretical level, but also on a very practical one. There are a number of obstacles which make it sometimes very difficult to perform effective multicultural communication. Thanks to the authors working in this 
area, one can identify categories of cultural differences, and based on this categorization try to avoid problematic situations in communicating with those representing other cultures.

The classical works of Geert Hofstede (2010) allowed already in 70's identifying four basic dimensions characterizing various cultures. Hofstede conducted one of the most comprehensive studies of how values in the workplace are influenced by culture. He analyzed a large data base of employee values scores collected by IBM between 1967 and 1973 covering 76 countries, from which he first used the 40 largest only and afterwards extended the analysis to 50 countries and 3 regions. Based on his research he identified four dimensions describing cultures: Power Distance, Individualism versus Collectivism, Masculinity versus Femininity, Uncertainty Avoidance. A fifth Dimension was added in 1991 based on research by Michael Bond who conducted an additional international study among students with a survey instrument that was developed together with Chinese employees and managers. That Dimension, is Long-Term Orientation and was applied to 23 countries. As Hofstede states: "The country scores on the dimensions are relative - societies are compared to other societies. Without make a comparison a country score is meaningless. These relative scores have been proven to be quite stable over decades. The forces that cause cultures to shift tend to be global or continent-wide. This means that they affect many countries at the same time, so that if their cultures shift, they shift together, and their relative positions remain the same. The country scores on The Hofstede Dimensions can also be found to correlate with other data about the countries in question. Some examples: Power distance is correlated with income inequality in a country. Individualism is correlated with national wealth. Masculinity is correlated negatively with the percent of women in democratically elected governments. Uncertainty avoidance is associated with the legal obligation in developed countries for citizens to carry identity cards. Long-term orientation is correlated with school results in international comparisons" (http://geert-hofstede. $\mathrm{com} /$ national-culture.html).

Hofstede research was criticized of course, mainly due to the very specific group of respondents (white collars, educated, male-dominated group of experts in management and IT); however the research still is treated as a base for discussions on cultural differences. This research was the first research to demonstrate in quantitative form, that cultural differences do exist and they are not only a matter of subjective judgement. It was relatively easy to apply this knowledge on the level of the trainings and workshops designed 
for business in order to make international communication more effective and positive.

Another author, dedicating his research to the issue of cultural differences was Edward Hall (1976) who defined: low-context cultures (place relatively less emphasis on nonverbal cues) and high-context cultures (place relatively more emphasis on nonverbal clues). The situational context is very important in actual conversations - Hall states - as it "suggests" how the words or non verbal communication should be interpreted. Differentiation proposed by Hall describes choices of communication styles translated into a culture that will cater to in-groups, an in-group being a group that has similar experiences and expectations, from which inferences are drawn. In a high context culture, many things are left unsaid, letting the culture explain. Words and word choice become very important in higher context communication, since a few words can communicate a complex message very effectively to an in-group (but less effectively outside that group), while in a lower context culture, the communicator needs to be much more explicit and the value of a single word is less important. In general one can say that lower context cultures are USA, Australia, English Canada, England, Ireland, New Zeeland and German language speaking countries. Higher context cultures are: Arab countries, African, Spanish and Portuguese language countries, and many others. The differentiation proposed by Hall, paid attention to different aspects of communication, than those chosen by Hofstede. At the same time Hall's proposal added some differences to the list already formed by Hofstede.

Another input to researching cultural differences was added by Richard Gesteland (2010), who identified five cultural variables that cause most of the problems for international negotiators and managers: Deal Focus/Relationship Focus, Direct/Indirect Communication Styles, Egalitarian/Hierarchical Business Behaviour, Monochronic/Polychronic Time Behaviour, and Reserved/Expressive Communication Styles. Some of elements that we see here were already tackled by other researchers (f.i. direct/indirect communication styles) but some add new ides to thinking of cultural differences.

Fons Trompenaars (2011) experienced cultural differences in his own life a lot: first at home, where he grew up speaking both French and Dutch, and then later at work with Shell in nine countries. Based on those experiences he started systematic observation over cultural differences and defined $7 \mathrm{di}$ mensions differing cultures: universalism vs. Particularism; neutral vs. emotional communication; individualism vs. collectivism in everyday orientation towards others; specific vs. diffuse (describing how much people separate 
private and working lives); achievement vs. ascription (how the social status is obtained - by own achievements or by ascription from somebody else); sequential vs. Synchronic cultures (dimension describing how people do things: one at a time or several things at once?); Internal vs. external control (the concept inspired by classical psychological research by Julian Rotter (1990) on the sense of control over external world surrounding human beings. While Rotter did his research on individuals, Trompenaars transferred this characteristic over social groups. Harry Triandis (1972), whose major research was the study of the relationship between culture and social behaviour also added valuable information to the research on cultural differences, especially that his findings were directly applied to the training program called Culture Assimilators created in USA.

On top of various dimensions differing cultures proposed by authors mentioned above there are also at least two other huge sources of cultural differences, which create a lot of difficulties in effective inter-cultural communication. Those differences are rooted in stereotypes and in various ways of using and interpreting nonverbal communication. Both those subjects were widely described in the literature: the classical research on stereotypes described in (Gerrig and Zimbardo, 2009; Aronson, Wilson and Akert, 2009) show that tendency to divide and categorize people based on given characteristics is one of the core functions of the human brain. It is most likely rooted in human evolution, while humanoids and later humans had to asses if what/who the meet was a danger or not. quick and relevant assessment was a guarantee for saving life, therefore no mistakes were allowed here. This tendency to asses and judge people still remains very vivid, although cultural conditions of human coexistence have changed significantly. Social psychologists and sociologists point out however that knowledge of stereotypes and consciousness on how the labelling mechanism works, allows controlling this process and reducing harm that can be done by improper judgements and categorizations.

Cultural differences in nonverbal communication and especially in gestures, but also mimics, and body posture show how much our communication is linked with various kinds of social agreements. In general majority of the gestures belong to the human etogram - if human being is treated as one of the mammals' species. Here we demonstrate behaviours that we share not only with some primates, but also with other mammals. Those gestures were formed based on evolutionary way of human species development, and they are heritage of tradition (social practice forming nonverbal communicates 
and reproducing knowledge of the way they function). Some of those bodylanguage communicate are rooted in the "animal" nature of human beings (for example it is believed that "bowing" in front of older, dominant person is a way of avoiding direct eye contact what could be treated as provocation for aggressive confrontation). Other gestures are determined by human genetic heritage typical for given individual (for instance the way we cross our arms on the chest is strictly determined by genes). Many others are defined by the cultures we live in (the best example is shaking head, which in majority of the countries around the globe is treated as confirmation, while in Bulgaria this movement expresses contradiction) (Grosse and Reker, 2010). The subject of nonverbal communication used by humans in communication is fascinating theme, especially when this knowledge is applied to much broader context of inter-species communication. Inter-species communication is a wonderful example of how misunderstaninding in inter-cultural communication work: what is given a certain meaning in one culture (or species) has absolutely different meaning in other culture (species). For instance in human - dog communication, non-verbal signals are often interpreted the way we-humans use them: if dog yawns, we tend to think dog ignores us, while among dogs this is calming down signal (Beaver, 1944; Miklosi, 2007). As I have stated before: having this knowledge of cultural differences in body-language, one realizes how much easier it is to communicate with others and to understand them properly.

On top of all those differences there also are differences in some social rules, which express expectations for certain, behaviours. Widely described already by Goffman (1967) meaning of face and face-saving is a good example of such - very important difference, which causes different behavioural responses to presented tasks. Face is the standing a person has in the eyes of others. The importance of "face" and face-saving varies across cultures. Some cultures value "face" more than others (for example Japan is a perfect example). Other cultures (USA) do not care about face all that much. Saving face takes usually form of preventing other person from being exposed to the fact that $\mathrm{s} /$ he has made a mistake in social behaviours (faux pas). Because saving face of the person is so important one would never admit that the person has made a mistake: has a spot on the tie, dirty blouse or smugged make-up. In cultures where saving face is important, members of the society avoid situations of such kind; while in other cultures there are no behavioural restrictions in this respect and one is allowed to express directly doubt, comment or question. Here is the example of practical problem in the workplace caused by this cultural difference: Japanese worker hired in American company is 
given instructions by the boss, but he did not understand instructions. He prefers to make mistakes in his job, to asking the boss for clarification. The interpretation for this situation is different for both sides: Japanese worker does not ask for clarification since this would present boss as unable to express himself clearly (which means losing face). Boss expects worker to ask for clarification, otherwise ascribes negative intentions to his behaviour of decreases opinion about his intellectual potential.

Short presentation made above lists main sources of misunderstandings in intercultural communication, but it also shows areas for improvement if one aims at mastering communicative skills.

\section{Improving intercultural communication}

It is of course possible to improve one's skills in intercultural communication. First of all it requires a lot of awareness and self-consciousness. Therefore it is worth to analyze own communication, own cultural codes and then to focus on learning about other cultures. As some empirical studies show (Benedict, 2005) this knowledge can be quite useful, however one has to bear in mind that there is a trick hidden here. In a way it is easiest to learn about own communication by observing others' communication. Detecting differences allows naming rules regulating mother culture. Again: certain kind of awareness and openness is required here and best - if this is connected with the ability of postponing own reactions in order of not imposing own interpretations over communicative act.

I propose to divide this process of improving intercultural communication in three steps. Step one is preparing for intercultural contacts at it does not take a lot of effort: collecting information about the culture to be communicated with is a crucial point. Getting knowledge of history, specificity of the country, its traditions and habits that people have there is very useful. In some sources, one can find "does and don'ts". Those are instructions based on general knowledge about rules functioning in given culture. It is important to keep in mind that those lists of does and don'ts are somehow stereotypical, but considering that there is a kernel of truth in each stereotype, it is good at least to know them. Certainly it is perfect to balance this kind of knowledge (typically obtained from handbooks, guidebooks, forums etc) with the personal experiences of those who have already been exposed to this specific culture. Those two opposite points of view (collective and individual) create counterbalance drawing areas of particular awareness. 
The second step is getting knowledge about some general, basic rules regulating inter-cultural contacts - those rules are often clearly expressed in folk proverbs (f.i.:"While Roma, do as the Romans do"). Those basic rules are: to demonstrate open and positive attitude with friendly interest and direct communication; as incoming person always adjust own behaviour to new culture; to treat representatives of new culture as partners not opponents; to observe and ask; and to differentiate surface and deep meaning. Especially last two rules are important. Human beings ten do interpret what they do observe immediately ("Person cries - is interpreted: person is sad). Those immediate interpretations tide our cognitive process and focus them on searching for proves to confirm those initial hypothesis. It is difficult later on to change interpretation (which of course does not have to be proper). Therefore the rule of dividing observation from interpretation is crucial. Another very important rule is to bear in mind "the iceberg metaphor of culture" (Hofstede, 2010). The concept inspired by Freudian division of human personality into consciousness and sub-consciousness. Similar culture can be divided into two spheres: the peak of the iceberg is the small proportion of the iceberg itself, but this is the only part visible to observer - the biggest part of the iceberg creature is hidden under the water surfaces, and one has to dive in order to see nit. Ignoring this huge massive ice can result in the tragic crash. Cultures function in similar ways: what is visible to observer are behaviours, small objects of everyday use, etc - while the real meaning of those behaviours and objects is hidden deep in the culture. Ignoring deeper meaning creates the risk of cultural clash and misunderstanding.

The third step is conscious development of competencies used in intercultural communication. Jurgen Bolten (2007) lists some of the competencies that he considers most important in effective communication between members of different cultures. Those are: asking' listening, empathy, observation, tolerance, distance to undertaken social roles, readiness to learn, readiness for acculturation, ability to form and maintain own borders, assertiveness, polycentric attitude and skill of meta-communication. It is easy to notice that competencies listed here, are necessary for effective communication in general: all of them are basically necessary if one wants to communicate with others also within own culture. Therefore persons communicating well in one culture, have no problems in intercultural communication, usually. 


\section{Conclusion}

In this text I have presented the idea how intercultural communication is important nowadays. This is the fact due to overwhelming multiculturalism taking place in the globalized world, where everybody is exposed to cultural differences. Lack of understanding in such conditions creates difficult conflicting situations, which can be relatively easily avoided however. Naming cultural differences by many various authors (Hall, Hofstede, Trompenaars, Triandis) helps to pay attention to certain areas of social rules forming context for daily communication. Knowledge of the sources of non-verbal signals (genetic, evolutionary and socio-cultural) allows to understand their relative meaning. Treating multiculturalism in a broad sense of various social rules accepted in given groups, shows how important effective communication is in everyday life. It also shows how much more diversed our societies are today comparing even to the situation two hundred years ago. Last but not the least: we can train ourselves in effective intra - and intercultural communication. Only this kind of self-motivated training allows us to avoid creating what is defined as "socially invisible groups" - groups that we do not understand, fear of, and just in case avoid in communicating. Every and each of human beings once belongs to such "invisible group", and no matter what type of group it is - it is always very unpleasant and humiliating experience. Therefore conscious actions focused on minimalizing the process of labelling persons as visible can improve the well-being of the $21^{\text {st }}$ century society in the Global Village.

\section{Biblioraphy}

Aronson, E., Wilson, T.D. and Akert R.M. 2010. Social psychology. Upper saddle river. New Jork: Prentice Hall.

Banaszak, G. and Kmita, J. 1994. Spoteczno-regulacyjna koncepcja kultury. Warszawa: Instytut Kultury.

Beaver, B.V. 1944. Canine behavior. Insights and answers. Philadelphia: Saunders Elsevier Inc.

Bennett, M.J. 1998. Basic concepts of intercultural communication. Boston: Intercultural Press.

Benedict, R. 2005. The chrysanthemum and the sword. New York: First Mariner Books. 
Bolten, J. 2007. Einführung in die Interkulturelle Wirtschaftskommunikation. Göttingen: Vandenhoeck \& Ruprecht.

Festinger, L. 1957. A theory of cognitive dissonance. Stanford: Stanford University Press.

Duno-Gottberg, L. 2003. Solventando las diferencias: La ideología del mestizaje en Cuba. Madrid: Iberoamericana, Frankfurt am Main: Vervuert.

Kohls, L.R. and Knight, J.M. 1994. Developing intercultural awareness. Boston: Intercultural Press.

Gerrig, R.J. and Zimbardo, P.G. 2009. Psychology and life. Boston: Allyn \& Bacon.

Gesteland, R. 2010. Cross-cultural business behavior: marketing, negotiating, sourcing and managing across cultures. Copenhagen: Copenhagen Business School Press.

Goffman, E. 1967. Interaction ritual-essays on face-to-face behavior. New York: Anchor Books.

Grosse, J. and Reker, J. 2010. Do not get me wrong. The global gestures guide. Verlag: Bierke Publishing.

Hall, E. 1976. Beyond the culture. New York: Anchor Books a Division of Random House Inc.

Hofstede, G. and Hofstede, J. 2010. Cultures and organizations. Software of the mind. Intercultural cooperation and its importance for survival. New York, London: McGrow-Hill Books.

Kymlicka, W. 1991. Liberalism, community and culture. Oxford: Clarendon Press.

Kymlicka, W. 1996. Multicultural citizenship: a liberal theory of minority rights. Oxford: Clarendon Press.

Miklosi, A. 2007. Dog behaviour, evolution and cognition. Oxford: Oxford University Press.

Rotter, J.B. 1990. Internal versus external control of reinforcement: a case history of a variable. American Psychologist. 45 (4), pp. 489-493.

Storti, C. 1994. Cross-cultural dialogues. Boston: Intercultural Press.

Taylor, Ch. 1991. Ethics of authenticity. Cambridge, Massachusttes and London: Harvard University Press.

Triandis, H.C., Vassiliou, V., Vassiliou, G., Tanaka, Y., and Shanmugam, A.V. 1972. The analysis of subjective culture. New York: Wiley.

Trompenaars, F. 2011. Riding the waves of culture: understanding diversity in global business. New York: McGraw-Hill.

www.geert-hofstede.com/national-culture.html (18.08.2018). 


\title{
Intercultural communication skills development as a basic requirement in the multicultural world
}

\begin{abstract}
In my text I try to argue that intercultural communication development is a complex process, which results in best effects if it is based on deep personal motivations. Those motivations, if directed towards understanding others, help to overcome barriers and own limits of an acting subject. I argue that the awareness of cultural differences and knowledge of their various understandings increase empathy and intercultural sensitivity. Solid communication skills allow confrontations with persons representing many various social categories and social groups. Such communication skills help also to eliminate the negative phenomenon of "invisible gropus": social partners who are pre-judged as difficult ones, therefore avoided in communication situations.
\end{abstract}

Keywords: communication, skills, intercultural communication, multiculturalism 